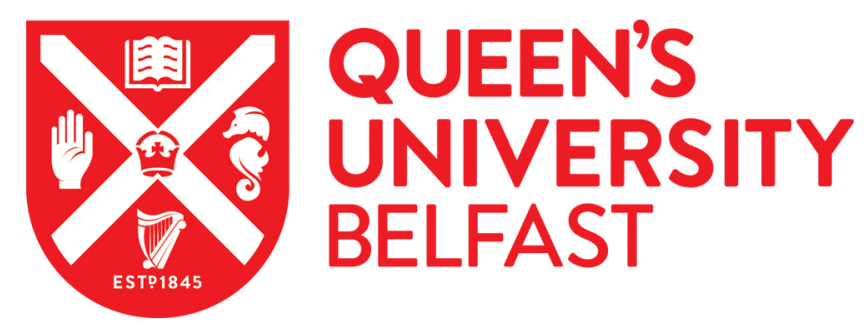

\title{
The direction of media influence: Real-estate news and the stock market
}

Walker, C. B. (2016). The direction of media influence: Real-estate news and the stock market. Journal of Behavioral and Experimental Finance, 10, 20-31. https://doi.org/10.1016/j.jbef.2016.02.001

Published in:

Journal of Behavioral and Experimental Finance

Document Version:

Peer reviewed version

Queen's University Belfast - Research Portal:

Link to publication record in Queen's University Belfast Research Portal

Publisher rights

(c) 2016 Elsevier. This manuscript version is made available under the CC-BY-NC-ND 4.0 license http://creativecommons.org/licenses/by-nc$\mathrm{nd} / 4.0$ / which permits distribution and reproduction for non-commercial purposes, provided the author and source are cited.

\section{General rights}

Copyright for the publications made accessible via the Queen's University Belfast Research Portal is retained by the author(s) and / or other copyright owners and it is a condition of accessing these publications that users recognise and abide by the legal requirements associated with these rights.

Take down policy

The Research Portal is Queen's institutional repository that provides access to Queen's research output. Every effort has been made to ensure that content in the Research Portal does not infringe any person's rights, or applicable UK laws. If you discover content in the Research Portal that you believe breaches copyright or violates any law, please contact openaccess@qub.ac.uk. 


\section{Accepted Manuscript}

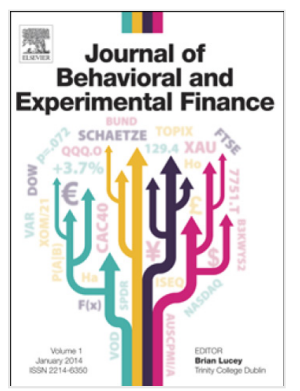

PII:

S2214-6350(16)00015-0

DOI: $\quad$ http://dx.doi.org/10.1016/j.jbef.2016.02.001

Reference: JBEF 68

To appear in: Journal of Behavioral and Experimental Finance

Received date: 11 December 2015

Revised date: 3 February 2016

Accepted date: 4 February 2016

Please cite this article as: Walker, C.B., The direction of media influence: Real-estate news and the stock market. Journal of Behavioral and Experimental Finance (2016), http://dx.doi.org/10.1016/j.jbef.2016.02.001

This is a PDF file of an unedited manuscript that has been accepted for publication. As a service to our customers we are providing this early version of the manuscript. The manuscript will undergo copyediting, typesetting, and review of the resulting proof before it is published in its final form. Please note that during the production process errors may be discovered which could affect the content, and all legal disclaimers that apply to the journal pertain. 
The Direction of Media Influence: Real-Estate News and the Stock Market

Dr Clive B. Walker ${ }^{\mathrm{a}}$

a Queen's University Management School, Queen's University Belfast, Belfast, UK c.walker@qub.ac.uk 


\section{The Direction of Media Influence: Real-Estate News and the Stock Market}

February 3, 2016

\section{Abstract}

This paper uses a novel identification strategy to test the influence of news media on the stock market. Because the stock market does not impact the media coverage of the housing market, a relationship between real-estate news and shares of companies engaged in the housing market is attributable media influence. I find that the content of reporting exhibits a significant relationship with stock returns, and the amount of news with the number of trades. These relationships exist even after controlling for known risk factors, housing market performance and intra-week correlation. This finding is consistent with the function of the media as a source of information and sentiment in financial markets.

JEL classification: G10, L82

Keywords: Media, Housing, News, Bubble, Stock Market, Real-Estate 


\section{Introduction}

It is difficult to identify what influence the media have on financial markets. With the advent of 24-hour news, the extent of media coverage is almost instantly determined by market performance. Furthermore, when movements are widely anticipated media coverage may even be influenced by future market performance. Consequently, media influence cannot be ascertained from a simple correlation with market performance. A solution is to use two separate markets - one to source the media coverage and another to test its impact. Provided the latter does not influence the former, it follows that any relationship is attributable to media influence. This article takes this approach to circumventing the causality issue by examining the influence of the news media on the UK stock market during the period 1993 to 2012. I test whether the media coverage of the residential housing market influences traders of company stocks related to the housing market (i.e., house building, residential property investment and development, and residential property fund management). The news articles identified do not report on the performance of the stock market or on companies engaged in the housing market. Controls are used on the performance of the housing market and company-specific risk factors when assessing the relationship between news media and the stock market. Thus a relationship with the stock market can be attributable only to the influence of the media on investors.

The main contribution of this paper is to the growing literature examining the causal impact of the media on financial markets. Focusing on retail investors, Engelberg and Parsons (2011) show that local newspaper coverage of earnings announcements strongly predicts local trading volume. By identifying differential media coverage of the same information event the authors do not assess the content of coverage, just whether earnings announcements were covered by local media. Peress (2014) identifies that an exogenous absence of media due to strike action reduces trading volume and intraday volatility. He concludes that media contribute to the efficiency of the market by improving information dissemination. By assessing market activity in the absence of media, no consideration is given for the content of media coverage. Dougal et al. (2012) do indirectly capture the content of media coverage by creating fixed effects for different authors of the Wall Street Journal's 'Abreast of the Market' column. While differing optimism and pessimism may be captured through the fixed 
effects so too will writing styles, article length, and the possibility that different journalists have different information on the market. Thus while the existing literature does suggest that the media have a significant causal impact on the stock market, the tonal content of media has not been tested with due consideration for causality. This article seeks to add to the literature by identifying if traders of stocks related to the housing market respond to the amount and sentiment of news media housing market articles with less ambiguity about the nature of any correlations identified.

This paper also contributes to the growing literature examining factors that influence the housing market. Given the importance of the housing market to the broader economy (Leung, 2004; Calomiris et al., 2012; Mian et al., 2011), a better understanding of the factors that may influence this market is of particular importance. While Soo (2013) and Walker (2013) quantify news media sentiment on the housing market and identify a relationship with house price changes, few studies have examined the causal impact of the media on the housing market. This is unsurprising for a number of reasons. The infrequency with which house prices are recorded prevents a granular analysis of the relationship between media coverage and house price changes. Further, the infrequency with which individuals buy or sell houses creates a significant lag between the media's influencing sentiment and this sentiment affecting market activity, creating the possibility that in the interim period factors other than the media have influenced individuals. Finally, as previously highlighted, since media coverage is determined by housing market performance, any relationship may be that of the housing market on the media rather than that of the media on the market. Using the stock market to estimate the effect of the media on housing market expectations circumvents these problems.

Mori (2015) examines the information diffusion process in the the US real estate investment trust (REIT) market and shows a relationship between lagged returns of companies with media coverage and the current returns of companies without media coverage, suggesting that the media play an important informational role in the market. Media coverage is of specific companies and the REIT market. This article builds on this work by looking at other industries affected by the housing market, examining a UK context and utilising media that does not reference any of the specific companies or industries analysed. 
To gauge the media effect, nearly 12,000 articles on the housing market in the Financial Times were identified. These articles were published between 1993 and 2012, providing 20 years of analysis. The boom in the UK housing market from 2002 onwards (Burnside et al. 2011; Whitehead and Scanlon, 2012), resulted in significant variation in the amount and content of news reporting, ensuring that the sample period is not limited to a boom or a bust housing market, but also includes periods of stability. Figure 1 shows that the growth in UK house prices reflected changes in average earnings until 2002, when this growth outstripped earnings growth, indicating a booming housing market. Average house prices continued to increase until mid2007, fell for the next 18 months and were then relatively stable to the end of 2012 . Bloomberg was used to create a portfolio of 41 companies listed on the London Stock Exchange whose primary activity concerns the UK residential property market. Measures of the amount and content of media coverage were used as explanatory variables for portfolio return premiums and volume, controlling for known risk factors and housing market performance.

The main finding of this article is that there is a significant relationship between the tonal content of the housing market articles published in the Financial Times and the return premium of companies involved in the housing market, suggesting that the media influence investor sentiment across markets. This finding is consistent with Tetlock (2007), since the tone of media reporting appears to approximate to investor sentiment. This finding is robust to controlling for known risk factors, such as broader market performance, the volume of trading, the January effect, the 2008 financial crisis, controlling for the performance of the housing market, using different measures of portfolio performance, different sample periods, different sets of housing market articles and different model specifications. Falsification tests showed this relationship to be non-spurious; no relationship was identified between future media coverage and current portfolio returns or media coverage and the returns of the FTSE Oil Index. As a final robustness check, to ensure that the stock market was not affecting the tone of media reporting, articles that referenced either the financial system or mortgagebacked securities were excluded from the analysis, and this did not alter the findings.

The second finding was that the number of articles published affects the volume of trading. This finding is robust to controlling for stock and housing market 
performance, using different measures of portfolio performance, different model specifications and different sample periods. However, when articles that reference the financial system or mortgage-backed securities were excluded from analysis, no significant relationship was identified. However, overall the findings suggest traders of stocks related to the housing market respond to the amount and sentiment of news media housing market articles.

\section{$<<$ INSERT FIGURE 1 HERE $>>$}

The rest of this article is structured as follows. Section two describes how housing market articles were identified in the Financial Times and how the sentiment of those articles was quantified. Section three details the portfolio used to assess media influence and the variables chosen to control for housing market performance. The model used is discussed in section four. The results are presented and discussed in section five. Section six provides a number of robustness tests to demonstrate that the results indicate a causal relationship rather than a mere correlation. The final section concludes with an overview and interpretation of the findings.

\section{Content Analysis}

News articles are sourced from LexisNexis, a searchable database of digitised print media. Although extensive microfilm and article records of newspapers exist, LexisNexis has two advantages over these formats. First, it is searchable by key words in the headline or main body of an article and LexisNexis-generated topic tags can be used to identify articles. This provides a systematic way of identifying housing market articles. Second, articles can be downloaded in electronic format, making it easier to prepare them for subsequent textual analysis.

For articles to influence traders, they must be read. While not all traders will have read all the relevant articles, to increase the likelihood of their doing so, I limited the news media coverage to the Financial Times, the financial newspaper with the largest UK circulation. Second, for articles to influence traders, the articles must bring about opinion change. Being perceived as a trustworthy source, the Financial Times may be supposed more likely to bring about opinion change than other medium. For example, the Financial Times has recently been used in the literature to provide a proxy for 
merger expectations (Siganos and Papa, 2014).

$<<$ INSERT TABLE 1 HERE $>>$

Articles were identified using LexisNexis's own housing market industry tag. LexisNexis define this tag as follows: "HOUSING MARKET targets financial conditions in the residential property industry, including statistics and forecasts for residential mortgage rates, home sales, property vacancies and other indicators." Table 1 shows the headlines of the first 10 articles identified by the "Housing Market Strong Reference Only" search tag for January 1993. Coverage focused on reporting the latest market changes, inferring future performance and government involvement in the market.

All articles were filtered to ensure that any correlation identified with the market was attributable to its having influenced traders' expectations of the housing market. Some articles explicitly referenced housing-related companies included in later analysis. To ensure that this did not cause any correlation between media coverage and stock returns, articles with headline references to these companies were removed. Headline references were used because they were the best indication that the article was about the company referred to. Companies often provide data and opinion on the housing market and hence are referenced in articles. For example, Savills, a leading estate agent, is referenced in 741 articles, but appears in the headline of only 24 of them. In the non-headline articles, Savills was providing insight into the state of the housing market, but in the headline articles, the Financial Times was reporting on Savills itself. An additional geographic filter was used to limit articles to the UK housing market. With companies included in the portfolio because their primary activity concerns the UK residential property market, there is little theoretical justification for supposing that articles on non-UK housing markets influenced investors in these stocks; thus articles with headline references to non-UK housing markets are excluded from the analysis. As a final filter, articles published at the weekend were excluded from analysis because they tended to be dominated by lifestyle pieces, which were unlikely to be of interest to stock traders. The filters excluded over half of the housing-market articles published in the Financial Times, mainly because they excluded non-UK and weekend articles. 
As Table 2 shows, the amount of housing market information presented by the Financial Times appears high, on average 4.67 articles per week. The amount of coverage varied from 0 to 19 articles per week. Figure 2 shows this variability and reveals the escalation and subsequent decline in the number of articles published per week on the housing market over the sample period. On average, the Financial Times published four articles per week from 1993 to 2001, seven articles per week from 2002 to 2008 and three articles per week for the remainder of the sample.

Article content was quantified using an approach similar to that of Tetlock (2007) and Tetlock et al. (2008). A content analysis software program, Diction, which uses a 10,000-word corpus and a series of dictionaries to score individual articles on semantic features, was used to assess sentiment. The fact that no individual associated with this study determined the dictionaries used removes bias in the scoring of articles. In addition the use of software removed inconsistency and time-varying judgment errors. Another advantage of using a software program is that it provides a spectrum of results: scores are numbers rather than categorical results, such as positive, neutral or negative.

Diction has a number of advantages over other content analysis software programs. Output is limited to five categories, removing possible bias should many categories need to be aggregated. Diction has recently been used extensively in studies in accounting, business and finance (Bligh et al., 2010; Abdelrehim et al., 2011; Craig and Brennan, 2012; Craig et al., 2012; Engelen et al., 2013; Allison et al., 2013).

\section{$<<$ INSERT TABLE 2 HERE $>>$}

Diction aggregates 35 subcategory scores to five composite scores, namely, activity, optimism, certainty, realism and commonality. Of the five categories constructed by Diction, certainty, activity, realism and commonality have no clear theoretical relationship with investor sentiment towards the housing market. Although one could assume that articles with greater conviction are more likely to have an impact on the market, it is not clear what this impact would be. The same is true for activity, realism and commonality. It is only the category of optimism that has a clear theoretical relationship with investor sentiment. The more optimistic an article is, the more likely is it to improve readers' expectations of housing market performance. This may cause 
higher stock prices, since investors believe that companies operating in such a market are likely to make higher profits. Thus the optimism score is aggregated to a weekly level to test the relationship between media content and the market. Optimism is defined as "Language endorsing some person, group, concept or event or highlighting their positive elements" (Diction User Manual, 2000) and is calculated as the aggregate of subcategories of the software, [Praise + Satisfaction + Inspiration] [Blame + Hardship + Denial $]$.

Loughran and McDonald (2011) highlight how the use of psychosocial dictionaries in financial markets may be inappropriate, since some words are not necessarily negative in a financial context e.g., "tax" or "liability". As this study focuses on article optimism, this problem is circumvented but not entirely removed, since some negative dictionaries are used when calculating article optimism. Because articles are not written about companies or the stock market, the text is less financial and more general in nature. However, if words were falsely assumed to be negative, this would have the effect of underestimating the article's optimism. Provided this underestimation is consistent, however, it should not increase the likelihood of finding no relationship with market variables, though the size of the coefficient may be underestimated.

\section{$<<$ INSERT FIGURE 2 HERE $>>$}

Data on the number of articles and article optimism are aggregated to a weekly level to ensure that observations are cited for each period. One problem with using weekly data is that in 47 of the 1,043 weeks, the Financial Times published no articles on the UK housing market. With media optimism normalised to 50.00, if no articles are published in a given period, the score drops to 0.00 , but this does not reflect the tone of the newspaper for the period. This is the primary reason why daily data are not used: on 4,390 of the 7,305 days in the sample period, the Financial Times did not publish an article on the housing market. For the weeks when no articles were published, the previous week's sentiment is assumed to be the sentiment still held by the newspaper and so the optimism score is the same as for the previous week. Nonetheless, in a later robustness check, weeks with no media coverage are excluded. 
Figure 2 shows the optimism score of housing-related articles in the Financial Times. It is important to note that the optimism score was normalised by Diction to 50 and small deviations from 50 reflected large variations in the content of articles. Table 2 shows that, with a mean of 49.56 , a standard deviation of 0.90 and a range of 46.01 to 54.47, the weekly scores have little variation. However, these small variations represent large changes in the sentiment of the articles. For example, article 1 in Table 3 has an optimism score of 48.01 and article 2 has a score of 52.01. Although the scores do not differ greatly, the content does. The first article warns borrowers against investing all their money in property, while the second article focuses on the way in which the property prices increase, writing that "the rampant housing inflation shows few signs of abating."

Two trends in Figure 2 are of particular note: first, the low optimism in the mid-1990s gave way to higher optimism by the early-2000s. That is, perhaps, unsurprising, given that the subdued house price growth that had prevailed for most of the 1990s was about to give way to a house price boom. Second, optimism fell markedly from 2006 onwards, nearly a year before house prices started to fall. These casual observations may imply that the sentiment of the Financial Times did not merely reflect changes in the housing market, but reflected expectations about future market performance.

\section{Data and Variables}

To assess how the media coverage of the housing market influences the stock market, a portfolio of companies whose main activities were in the UK residential housing market was constructed. Four Industry Classification Benchmarks were used to identify companies: Construction and Materials (CM); Real Estate Investment and Services (REIS); Real Estate Investment Trusts (REIT); and Household Goods and Home Construction (HGHC). Bloomberg was used to identify companies from the above sectors listed on the London Stock Exchange for any period between 1993 and 2012, with 38 CM companies, 88 REIS, 21 REIT and 26 HGHC companies identified.

Bloomberg company descriptions were used to ensure that company activities were primarily in the UK residential property market. After filtering on this basis, the portfolio consisted of $41 \mathrm{UK}$ residential property companies, comprising 22 REIS, 11 
HGHC and six CM companies. Only 2 REITs were included in the initial analysis because the industry is dominated by companies which are primarily active in the commercial, not the residential property market. While these markets are undoubtedly linked, these companies are excluded because the articles used in this study cover the residential market alone. Table 4 lists the companies included in the portfolio, their sector and the years for which they were included in the sample.

\section{$<<$ INSERT TABLE 4 HERE $>>$}

Weekly closing prices were used to construct an equally-weighted portfolio of housing company stocks and calculate the geometric average return for the portfolio each week. A price-weighted portfolio was also used as a robustness check. The weekly rate of discount on two-year Treasury bills was subtracted from the average return to get the return premium. The mean weekly return premium on the portfolio from 1993 to 2012 was $-0.01 \%$, with the median return being $0.09 \%$. If the period following the end of the housing boom in July 2007 is excluded, mean weekly returns increased to $0.14 \%$. The lowest weekly return of $-13.87 \%$ occurred on $10^{\text {th }}$ October 2008: the highest return of $12.38 \%$ occurred on $10^{\text {th }}$ April 2009.

\section{$<<$ INSERT FIGURE 3 HERE $>>$}

Figure 3 shows the relative performance of the housing stocks portfolio compared with the FTSE 100. The FTSE 100 series is dominated by two large price reversals: the dot-com bubble of 2000 and the financial crisis following 2007. The housing portfolio series is markedly different, being relatively unaffected by the dot-com bubble and showing more acute escalation and contraction from 2001 onwards than the broader market did.

The portfolio had a mean weekly sales volume of $87.3 \mathrm{~m}$. The standard deviation of $86.7 \mathrm{~m}$ was the result of the escalation in trading volume from 2006 onwards. Excluding this period, the standard deviation was $28.8 \mathrm{~m}$. The highest level of weekly trading volume was $88.5 \mathrm{~m}$ in $13^{\text {th }}$ June 2008 , while the lowest level was 657,101 on $1^{\text {st }}$ January 1999 . The natural log of volume sales was used in the regression analysis, with Table 2 showing values ranging from -0.42 to 6.79 , with a mean of 4.00 and a standard deviation of 0.99 . 
Given that the UK housing market performance is likely to affect the companies included in the analysis, a variable was created by including the average house price announcements by the Nationwide in the week that they were published. Weeks with no house price announcement were given a value of zero. House price changes were announced in 227 of the 1,043 sample weeks, with an absolute average of $2.20 \%$. The consistency and size of price increases from the mid-1990s until mid-2007 was one of the defining characteristics of the housing market over this period. The cumulative price change from January 1996 to July 2007 was $128 \%$, and there were 120 price increases announced in this period as compared to 13 decreases.

The same approach was used to create a weekly series of the monetary policy announcements of changes to the base rate. The base rate changed in 56 of the 1,043 weeks in the sample. The average absolute change was $0.96 \%$; the largest increase was $0.5 \%$, which was made three times before 1996, while the largest decrease was $1.5 \%$ in November 2008.

\section{Hypotheses and Model}

To test the effect of media, I regressed the return premium and trading volume of a portfolio of stocks whose primary activity concerned the UK residential property market against the number of housing market articles published in the Financial Times and the optimism of these articles. Following Peress (2014), where the publication of articles is found to improve the dissemination of information in equity markets, I assumed that the number of articles approximates the amount of information published by the media. By assessing the relationship between market variables and the number of articles published, the informational role of mediaasking whether traders react to more news - could be tested. According to Tetlock (2007), media optimism is assumed to approximate investor sentiment. By assessing the relationship between market variables and article optimism, the behavioural role of the media - asking whether traders react to the tone of articles - could be tested.

Variables thought to influence stock returns were included as controls. Chen (2012) highlights the important relationship between trading volume and stock returns and for this reason volume is included. The performance of the broader market as measured by the FTSE 100 returns is used as a control also. Since the performance of 
the housing market is likely to affect the stock prices of companies engaged in the housing market, average house price changes as announced by the Nationwide building society were included. Fatnassi et al. (2014) mentions the importance of monetary policy changes to the performance of companies engaged in the housing market; consequently changes to the Bank of England base rate were also included. In a similar methodology to Demirgüç-Kunt et al. (2013) and Haas and Van Lelyveld (2014), a further control for the effect of the financial crisis was included as a dummy variable, that is, one from July 2007 to January 2009 and zero otherwise. Finally, and of particular note since small-capitalisation stocks are used in analysis, a January dummy was included to capture the January Effect (Rozeff and Kinney, 1976).

The initial model used was an ordinary least squares (OLS) regression with NeweyWest robust standard errors to correct for autocorrelation and heteroskedasticity, as detailed in Equation (1) below. Findings were robust to different specifications, described later. The basic models are:

$$
\begin{gathered}
\text { RtPrem }_{t}=\beta_{0}+\beta_{1} \text { Opt }_{t}+\beta_{2} \text { Art }_{t}+\beta_{3} \text { Vlm }_{t}+\beta_{4} \text { FTSE }_{t}+\beta_{5} \text { Crisis }_{t} \\
+\beta_{6} N^{\prime} \text { wide }_{t}+\beta_{7} \text { OBR }_{t}+\beta_{8} \text { Jan }_{t}+\varepsilon_{t} \\
\text { Vlm }_{t}=\beta_{0}+\beta_{1} \text { Opt }_{t}+\beta_{2} \text { Art }_{t}+\beta_{3} \text { RtPrem }_{t}+\beta_{4} \text { FTSE }_{t}+\beta_{5} \text { Crisis }_{t} \\
+\beta_{6} N^{\prime} \text { wide }_{t}+\beta_{7} \text { OBR }_{t}+\beta_{8} \text { Jan }_{t}+\varepsilon_{t}
\end{gathered}
$$

where $R t$ Prem $_{\mathrm{t}}$ denotes mean return premium on portfolio in week $\mathrm{t}, O p t_{\mathrm{t}}$ denotes the optimism of Financial Times articles in week t, Art denotes the number of housing market articles published in the Financial Times in week $\mathrm{t}, V I m_{\mathrm{t}}$ denotes the mean volume of sales on portfolio in week $\mathrm{t}, F T S E_{\mathrm{t}}$ denotes the return of the FTSE 100 index in week $\mathrm{t}$, Crisi $\mathcal{S}_{\mathrm{t}}$ denotes the financial crisis dummy, $N$ 'wide $\mathrm{t}_{\mathrm{t}}$ denotes the Nationwide announcements of house price changes in week $t, O B R_{t}$ denotes changes to the Bank of England base rate in week $\mathrm{t}$ and $\mathrm{Jan}_{t}$ denotes a January dummy. The effect of the media on trading volume was estimated by using volume as the dependent variable and the return premium as an additional independent variable, as shown in Equation (2).

\section{Results}

To ensure that correlations are not due to a common time trend, augmented Dickey Fuller tests were used to determine whether the variables were all of the same order of 
integration. All variables are stationary and of the same order of integration. The residuals of the OLS regression of the variables were then tested for cointegration using an augmented Dickey Fuller test and Engle and Yoo (1987) critical values. When the variables are modelled, the resultant residuals are stationary.

\section{$<<$ INSERT TABLE 5 HERE $>>$}

To test the stability of the media-market relationship, four variants of the model were run, adding explanatory variables to the model at each pass. Later, the results were tested for robustness against different time periods, different calculations of returns and different model selections. Columns 1-4 in Table 5 show a significant positive relationship between the optimism of the Financial Times housing market coverage and the return premium on the portfolio of housing-companies stock. The finding is significant with no control variables and controlling for volume and the FTSE 100 return. Even after controlling for housing market performance, base rate changes and a January effect, Financial Times optimism is still significant. Furthermore, the inclusion of a simple dummy variable for the financial crisis does not cause the optimism variable to become insignificant, although the magnitude of the coefficient drops. Thus a significant relationship is found between stock market returns and the content of the housing market reports in the Financial Times, even when controlling for known risk factors and housing market performance.

Looking at the other variables in the model, the portfolio return premium exhibits a significant relationship with volume, the FTSE 100 returns, changes to the Bank of England's base rate, the January dummy and the financial crisis. No significant relationship was identified between returns and the number of housing market articles published in the Financial Times. House price announcements by the Nationwide do not appear to be significant. While no significant relationship was identified between current house price announcements and portfolio returns, a significant relationship was identified when the next period's house price announcement was used in Equation 1. This does not affect any other relationships in the model. Thus it would appear the market is able to predict house price announcements one week in advance. This may not be surprising, given that the time needed to generate an average house price series facilitates the leaking of such information. 
Table 5 also shows how the media affect the volume of sales of portfolio stock. With no control variables, both the number of housing market articles published in the Financial Times and the optimism of these articles are significantly correlated with volume. Increasing newspaper optimism is associated with a fall in the amount of trades of portfolio stock, as indicated by the negative coefficients of the Financial Times Optimism variable. This is consistent with Tetlock's (2007) suggestion that traders respond more to negative than positive news. Increasing amounts of housing market news are associated with increased levels of trading volume, suggesting that traders may be responding to the increased information on the housing market coming from the media. These significant relationships exist when controls are introduced for portfolio and FTSE 100 returns, changes in the official bank rate, house price announcements and the January effect. When a control is introduced for the financial crisis both media variables drop in significance.

\section{$<<$ INSERT TABLE 6 HERE $>>$}

\section{Robustness}

To test that results are not driven by the portfolio measurement procedure, different weightings were considered for the sake of robustness. First, rather than use an equally-weighted portfolio, a price-weighted portfolio was used. As Table 6 shows, this does not alter previous findings: a significant positive relationship was identified between the optimism of the Financial Times and the return premium of housing

portfolio stock, and no significant relationship was identified between the number of articles and returns. When volume is the regressand, a marginally significant relationship with optimism is identified and a significant relationship with the number of articles is identified. As an additional robustness check, the median, rather than the mean, return and volume were used. Table 6 shows that this does not alter the main findings of this article, either — a significant relationship was identified between optimism in the Financial Times and the median return premium; and between the number of housing market articles and their volume.

As a further robustness check, the original model was modified to include one lag of the dependent variable as an independent variable, that is, made into an autoregressive model. Table 6 shows that this does not alter the findings of significant relationships 
between optimism and returns or between the number of articles and their volume. Additionally, weeks when no housing market articles were published were excluded. As Table 6 shows, this reduces the number of observations from 1,043 to 996, but does not alter the findings of the paper.

The use of weekly rather than daily data creates the possibility that the performance of housing equities at a start of a given week affects newspaper coverage later in the week. If there is unusual activity in the market for housing equities say on Monday, this could result in the editorial staff of the Financial Times commissioning an article on the general state of the housing market to be published later in the week. This type of article will not be captured through the filters used to identify articles relating to housing equities and may undermine the identification strategy used to test the influence of news media on the stock market.

There were 1,955 articles published on a Thursday or Friday with 2,837 published Monday to Wednesday. This is remarkably close to the number we would expect: $40.8 \%$ or $20.4 \%$ on each day. The articles most likely to be commissioned in response to housing equity volatility are commentary articles. Of the articles published on Monday through Wednesday $6.63 \%$ are commentary compared to $7.36 \%$ on Thursday or Friday. There is no statistically significant difference in word count, characters analysed, page, length of words, number of different words or most importantly for this study optimism between commentary articles published on Thursday or Friday. All commentary articles published on Thursday or Friday were read to ascertain if they were in response to housing equities. As best as I can see, the majority of articles were in response to factors likely to be exogenous from housing equities and thus it is unlikely that they were written in response to equity market movements. For example, government action (or inaction) is a frequent topic in editorials accounting for $18 \%$ of commentary articles published on Thursday or Friday, actions (or again inactions) of the Bank of England accounts for $24 \%$ and the formation and recovery from the housing bubble accounts for $27 \%$ of the commentary articles.

Since the effect of media sentiment is expected to be short-lived, using daily data is the approach most likely to identify a relationship between the media and market activity. Given the non-daily coverage of the housing market, this study uses weekly data as an imperfect alternative. Lagged media coverage is used as a robustness check 
to ensure results are not driven by intra-week correlation between stock market activity and media coverage. While lagging media coverage circumvents the issue around stock market activity early in the week affecting media coverage later in the week, it is likely to underestimate the relationship between media and market as the effect of sentiment is likely to have been incorporated and reversed in market variables (Tetlock, 2007). Table 7 shows the results when the original model is altered to include lagged media variables. With no control variables, a significant relationship is identified between both lagged media optimism and the lagged number of articles and the return premium and volume of housing equity stocks. When the control variables are introduced, significant relationships are still identified, but the size of the effects are smaller than that found in Table 6. This is unsurprising given that the potential lag between media being read and when the effect is assessed is 12 days.

To address the issue around intra-week correlation without introducing significant lags between the media being read and its affect being measured, media coverage on Thursdays and Fridays is excluded, which reduces the likelihood that media coverage reflects market activity from earlier in the week. The problem with this approach is that it significantly reduces the number of housing market articles by over $40 \%$ and still introduces a lag into analysis — with three days passing between the media being read and when the effect is assessed. However, Table 7 shows that this does not alter the main findings of this paper - there still exists a significant relationship between media coverage of the housing market and the performance of equity stock. The relationships are weaker, with no controls the relationship between returns and optimism drops in significance and size.

Since the 2008 financial crisis was inherently tied to the performance of the housing market, two additional robustness checks were used to ensure that stock market performance did not cause media sentiment. First, the period after 2003 was excluded from analysis. Table 6 shows that this did not change the main finding of this article: a significant positive relationship was identified between optimism and portfolio returns. The positive relationship between the volume of sales and the number of housing market articles published weakens from being significant at 5\% to $10 \%$. As a second check against the main findings being driven by the financial crisis of 2007 , news articles were filtered to exclude any reference to either mortgage-backed 
securities or the financial system. Table 6 shows that doing this did not change the main finding of this article: a significant positive relationship was identified between media optimism and portfolio returns. However, the relationship between the number of articles and the volume of sales was no longer significant, suggesting that the amount of information on the housing market published by the media did not influence the stock market.

As a final robustness check, falsification tests were used to establish if a significant relationship could be identified between variables that have no theoretical link. While it is conceivable that the media coverage of the housing market is linked to economic or financial cycles and thus market indices such as the FTSE 100 or a bank index, media coverage has no clear theoretical link with the FTSE All-Share Oil \& Gas Producers Index returns (FTSE OIL) and we would expect no relationship to be identified with media coverage in practice. If a link were found, it might be indicative of media coverage approximating an unidentified variable, rendering the previous interpretation of results void. Thus FTSE OIL returns replace portfolio returns as the dependent variable in the basic model to test if the previous results were spurious. No significant relationship was identified with any of the media variables, indicating that the media coverage was not capturing an unknown effect. In addition, alternative Diction sentiment measures which have no clear theoretical relationship with portfolio returns were used in place of the optimism variable. When 'commonality', 'realism', and 'activity' were included in the basic model, no significant relationship was identified with returns. When 'certainty' was used in the basic model, a significant relationship was identified; this may be unsurprising, given the anticipated relationship between uncertainty and stock returns. Finally, since future media articles cannot influence current investor behaviour, we would expect no relationship between portfolio returns and lead media variables. When the lead media variables were used in the original model, no relationship was identified between the next period's media variables and this period's median or price-weighted portfolio returns. While a relationship between lead media and geometric mean returns was identified at the $10 \%$ significance level, it was not unexpected, given the autocorrelation present in this measure of portfolio performance.

\section{Conclusions}


This article has shown that media influence extends beyond the market on which it is reporting, and, in doing so, circumvents the causality issues usually prevalent when studying media influence in markets. By identifying media coverage which is not influenced by market performance, but may influence trader opinions, I have shown that any link between media coverage and market variables must be attributable to the media's influence on opinions. Furthermore, since reporting can affect the stock market only by changing traders' expectations of the housing market, this study also tests the effect of the news media on housing market expectations, with greater data frequency and less causal ambiguity than if the housing market had been studied in isolation.

Both the main results and subsequent robustness tests identify a link between the optimism of media reporting and portfolio return premiums. This suggests that media sentiment influences trader sentiment and thereby market prices. Further, it would appear that the media play an important role in affecting housing market expectations during booms, a finding similar to that of Soo (2013) and Walker (2014). While recent literature has demonstrated the causal impact of the media in the financial markets, this is the first article to do so using measures on the sentiment of reporting.

This paper establishes a link between the amount of media reporting and the volume of trades, a finding similar to that in Fang and Peress (2008). Yet, by establishing that media reporting is not influenced by market performance, the direction of influence is clearer - because the media are not publishing more housing market articles, owing to changes in the stock market, it must be the case that traders are reacting to the amount of information published by the media. Given the relative infrequency with which housing market data are published - either monthly or quarterly — it may be that the Financial Times is able to provide information to traders with greater frequency and thereby affect the market. Thus, the media appear to play both an informational and a behavioural role in the market - traders react both to the amount and the content of media coverage. 


\section{Acknowledgements}

With thanks to John Turner, Gareth Campbell, Emiliya Lazarova, Graham Brownlow and Thankom Arun for their helpful comments. 


\section{REFERENCES}

Abdelrehim, N., Maltby, J. and Toms, S., 2011. Corporate social responsibility and corporate control: The Anglo-Iranian Oil Company, 1933-1951. Enterprise and Society, 12, 824-862.

Agnello, L. and Schuknecht L., 2011. Booms and busts in housing markets: Determinants and implications. Journal of Housing Economics, 20, 171-190.

Allison, T.H., McKenny, A.F. and Short, J.C., 2013. The effect of entrepreneurial rhetoric on microlending investment: An examination of the warm-glow effect. Journal of Business Venturing, 28, 690-707.

Bhattacharya, U.I., Galpin, N., Ray, R. and Yu, X., 2009. The role of the media in the Internet IPO bubble. Journal of Financial and Quantitative Analysis, 44, 657-682.

Bligh, M., Merolla, J., Schroedel, J.R. and Gonzalez, R., 2010. Charisma under crisis: Presidential leadership, rhetoric, and media responses before and after the September 11th terrorist attacks. The Leadership Quarterly, 15, 211-239.

Burnside, C., Eichenbaum, M., and Rebelo, S., 2011. Understanding Booms and Busts in Housing Markets. Working Article. National Bureau of Economic Research, Cambridge, MA.

Calomiris, C., Longhofer, S.D. and Miles, W., 2012. The housing wealth effect: The crucial roles of demographics, wealth distribution and wealth shares. Working Paper 17740, National Bureau of Economic Research, Cambridge, MA.

Campbell, G., Turner, J.D. and Walker, C.B., 2012. The role of the media in a bubble: Evidence from the British railway mania. Explorations in Economic History, 49, 461481.

Chen, S.S., 2012. Revisiting the empirical linkages between stock returns and trading volume. Journal of Banking and Finance, 36, 1781-1788.

Craig, R. J. and Brennan, N.M., 2012. An exploration of the relationship between language choice in CEO letters to shareholders and corporate reputation. Accounting Forum, 36, 166-177.

Craig, R., Mortensen, T. and Iyer, S., 2012. Exploring top management language for signals of possible deception: The words of Satyam's chair Ramalinga Raju. Journal of Business Ethics, 113, 333-347.

Demirgüç-Kunt, A., Detragiache, E. and Merrouche, O., 2013. Bank capital: Lessons from the financial crisis. Journal of Money, Credit and Banking, 45, 1147-1164.

Diction 5.0 User Manual. 2000. Digitext, Inc. Austin, Texas.

Dougal, C., Engelberg, J., García, D. and Parsons, C.A., 2012. Journalists and the stock market. Review of Financial Studies, 25, 639-679.

Engelberg, J. and Parsons, C.A., 2011. The causal impact of the media in financial markets. Journal of Finance, 66, 67-97.

Engelen, A., Neumann, C. and Schmidt, S., 2013. Should entrepreneurially oriented firms have narcissistic CEOs? Journal of Management, 20, 1-24.

Engle, R.F. and Yoo, B.S., 1987. Forecasting and testing in co-integrated systems. Journal of Econometrics, 35, 143-159.

Fang, L. and Peress, J., 2009. Media coverage and the cross-section of stock returns. 
Journal of Finance, 64, 2023-2052.

Fatnassi, I., Chaouachi S., Zied F. and Maatoug, A.B., 2014. Effects of monetary policy on the REIT returns: Evidence from the United Kingdom. Research in International Business and Finance, 32, 15-26.

Foote, C. L., Gerardi, K. S. and Willen, P. S., 2012. Why did so many people make so many ex post bad decisions? The Causes of the Foreclosure Crisis, National Bureau of Economic Research Working Paper, 18082.

Haas, R. and Van Lelyveld, I., 2014. Multinational banks and the global financial crisis: Weathering the perfect storm? Journal of Money, Credit and Banking, 46, 333364.

Kearney, C. and Liu, S., 2014. Textual sentiment in finance: A survey of methods and models. International Review of Financial Analysis, 33, 171-185.

Leung, C., 2004. Macroeconomics and housing: a review of the literature. Journal of Housing Economics, 13, 249-267.

Loughran, T. and McDonald, B., 2011. When is a liability not a liability? Textual analysis, dictionaries, and 10-Ks. Journal of Finance, 66, 35-65.

Mian, A., Rao, K. and Sufi, A., 2011. Household balance sheets, consumption, and the economic slump. Working Article. National Bureau of Economic Research, Cambridge, MA.

Mori, M., 2015. Information Diffusion in the U.S. Real Estate Investment Trust Market. Journal of Real Estate Financial Econonomics, 51:190-214.

Muellbauer, J. and Murphy, A., 2008. Housing markets and the economy: The assessment. Oxford Review of Economic Policy, 24, 1-33.

Peress, J., 2014. The media and the diffusion of information in financial markets: Evidence from newspaper strikes. Journal of Finance, doi: 10.1111/jofi.12179, accessed 29 September 2014.

Rozeff, M.S. and Kinney, W. R. Jr., 1976. Capital market seasonality: The case of stock returns. Journal of Financial Economics, 3, 379-402.

Shiller, R.J., Irrational Exuberance, New Jersey: Princeton University Press, 2005.

Shiller, R.J., The Subprime Solution, New Jersey: Princeton University Press, 2008.

Shiller, R.J. and Akerlof, G.A. Animal Spirits: How Human Psychology Drives the Economy and Why It Matters for Global Capitalism, New Jersey: Princeton University Press, 2009.

Siganos, A. and Papa, M., 2014. FT coverage and UK target price run-ups. The European Journal of Finance, doi: 10.1080/1351847X.2014.924077, accessed 11 February 2015.

Smales, L. A., 2015. Time-variation in the impact of news sentiment. International Review of Financial Analysis, 37, 40-50.

Soo, C., 2013. Quantifying animal spirits: News media and sentiment in the housing market. Ross School of Business Working Paper, No. 1200.

Taylor, J. B., 2007. Housing and monetary policy. National Bureau of Economic Research Working Paper, 13682.

Tetlock, P.C., 2007. Giving content to investor sentiment: The role of the media in the 
stock market. Journal of Finance, 62, 1139-1168

Tetlock, P.C., Saar-Tsechansky, M. and Macskassy, S., 2008. More than words: quantifying language to measure firm's fundamentals. Journal of Finance, 63, 14371467.

Walker, C., 2014. Housing booms and media coverage. Applied Economics, Vol. 46, No. 32, 3954-3967.

Whitehead, C. and Scanlon, K. Global Housing Markets, Crises, Policies and Institutions, New Jersey: John Wiley and Sons, Inc., 2012. 


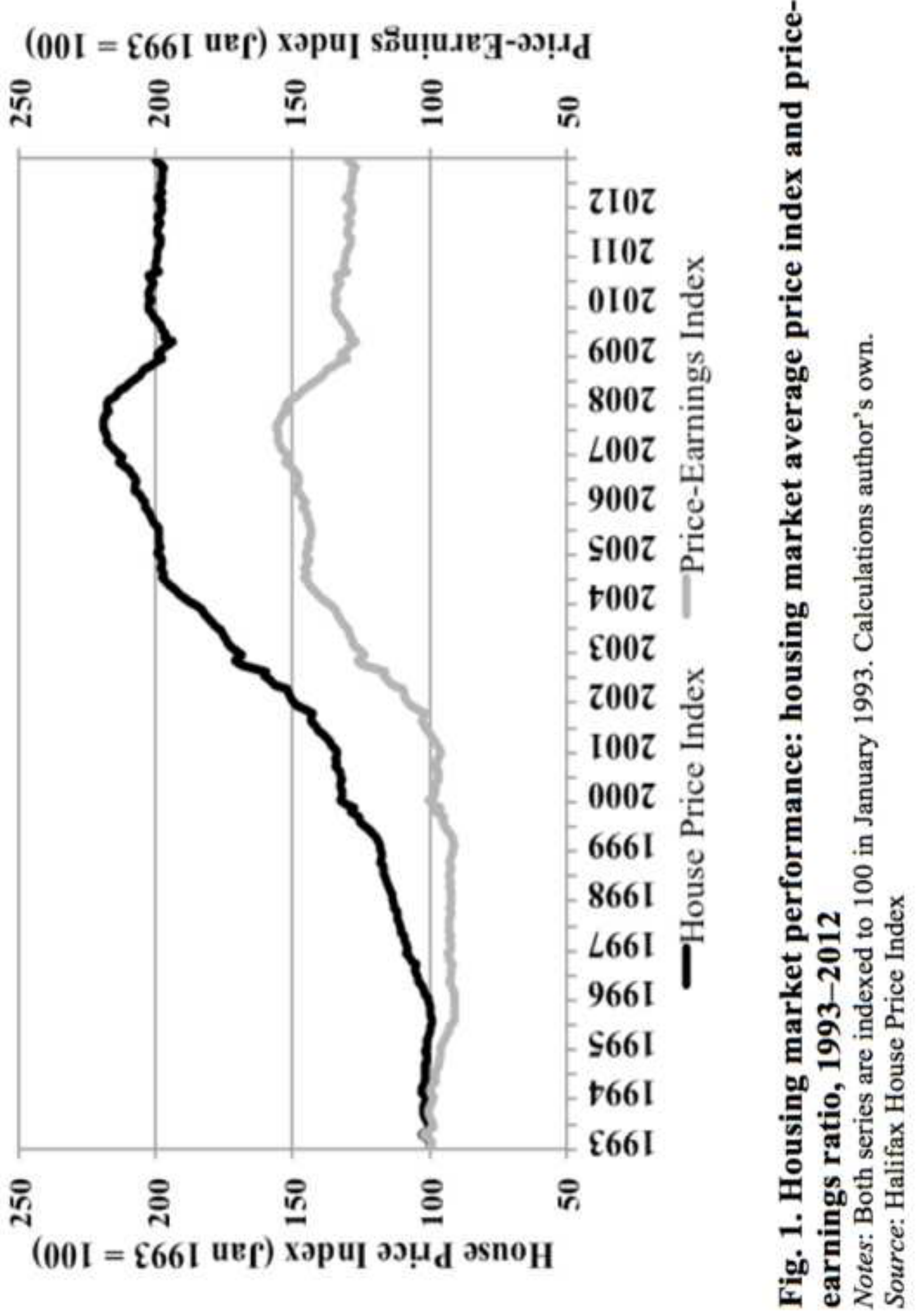




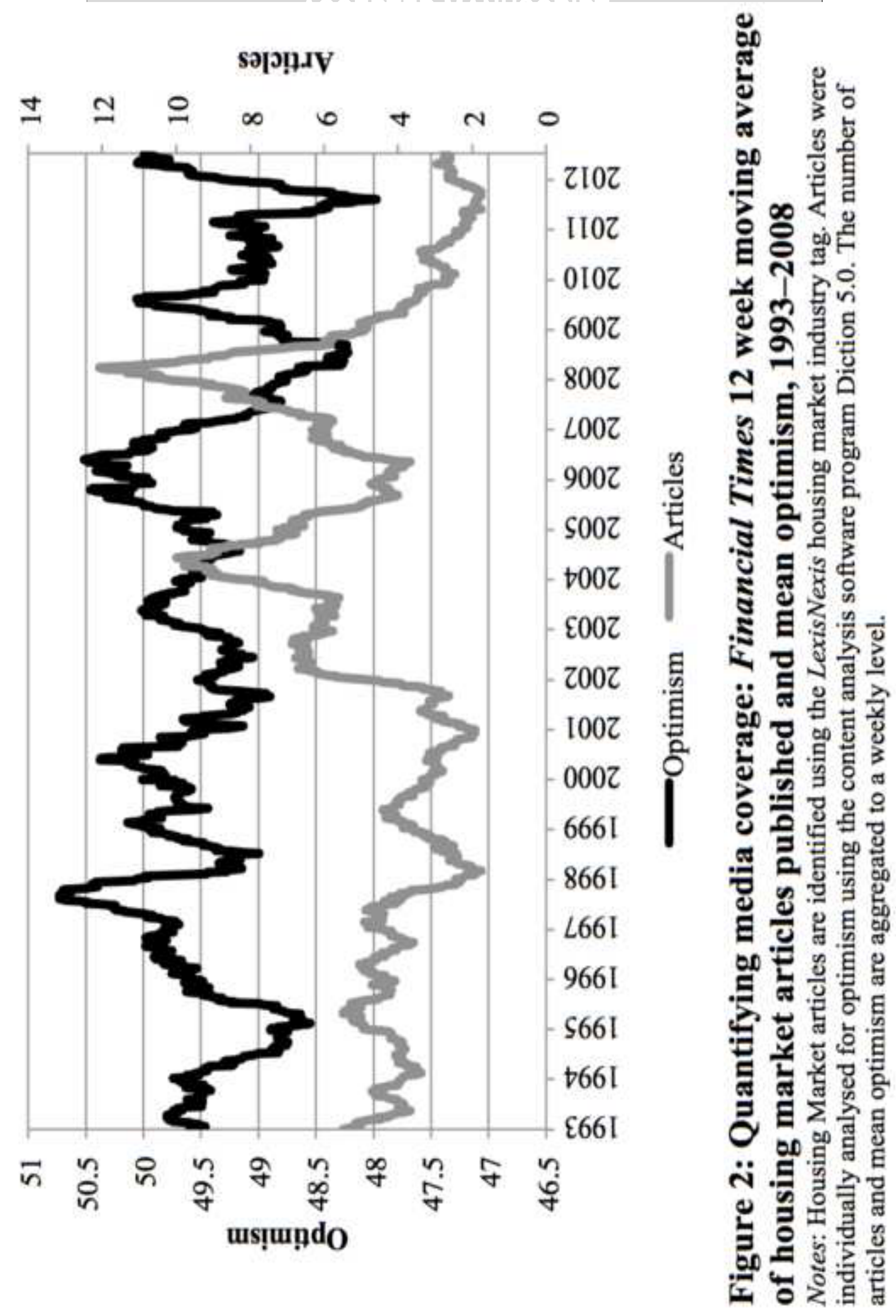



Table 1. Housing market news articles

\begin{tabular}{lccc}
\hline \hline Headline & Date & Page & Words \\
\hline Finance and the Family: Slow but sure comeback - The Home & $02 / 01 / 1993$ & 4 & 668 \\
Market Will Begin to Move in 1993 & $04 / 01 / 1993$ & 35 & 523 \\
Economics: Policy Questions Dominate in Germany and the UK & & 5 & 263 \\
Homes 'undervalued' for Council Tax: Institute of British & $06 / 01 / 1993$ & 5 & 240 \\
Geographers Conference & $06 / 01 / 1993$ & 12 & 284 \\
Abolish Housing Subsidy & $07 / 01 / 1993$ & 6 & 287 \\
Housing Market Shows Stability & $07 / 01 / 1993$ & 6 & 117 \\
Number of News Houses Built Last Year Fell & $08 / 01 / 1993$ & 6 & 314 \\
Halifax Says House Prices Fell By 0.6\% Last Month & $08 / 01 / 1993$ & 3 & 152 \\
Tokyo home prices in biggest fall since 1979 & $09 / 01 / 1993$ & 4 & 486 \\
A bigger dose of gloom & $09 / 01 / 1993$ & 2 & 120 \\
House prices show fall in December - At a glance & ' & & \\
\hline
\end{tabular}

Notes: All articles sourced from the Financial Times using LexisNexis ‘Housing Market Industry’ Tag. 
Table 2. Summary statistics of model variables, 1993-2012

\begin{tabular}{|c|c|c|c|c|c|c|}
\hline Variable & Units & Mean & Median & $\begin{array}{l}\text { Std. } \\
\text { Dev. }\end{array}$ & Min. & Max \\
\hline Mean Return Premium & $\%$ & -0.01 & 0.09 & 2.05 & -13.94 & 12.36 \\
\hline $\begin{array}{l}\text { Price Weighted Return } \\
\text { Premium }\end{array}$ & $\%$ & 0.32 & 0.52 & 4.67 & -23.47 & 26.18 \\
\hline Volume & $\log$ & 4.00 & 4.01 & 0.99 & -0.42 & 6.79 \\
\hline FT Articles & No. & 4.67 & 4.00 & 3.17 & 0.00 & 19.00 \\
\hline FTOptimism & $\begin{array}{l}\text { Standardised } \\
\text { to } 50.00\end{array}$ & 49.46 & 49.50 & 1.34 & 40.40 & 56.82 \\
\hline FTSE 100 Return & $\%$ & 0.10 & 0.21 & 2.40 & -21.05 & 13.41 \\
\hline Crisis & Dummy & 0.10 & 0.00 & 0.30 & 0.00 & 1.00 \\
\hline Nationwide & $\%$ & 0.12 & 0.00 & 0.52 & -3.00 & 3.50 \\
\hline OBR & $\%$ & -0.01 & 0.00 & 0.09 & -1.50 & 0.50 \\
\hline January & Dummy & 0.08 & 0.00 & 0.28 & 0.00 & 1.00 \\
\hline
\end{tabular}

Notes: Media articles identified using LexisNexis "Housing Market Strong Reference Only" Tag. FT denotes the Financial Times; FT Optimism calculated using Diction 5.0. Returns and Volume relate to the portfolio of stocks created by author. Nationwide denotes house price changes as announced by the Nationwide Building Society. OBR denotes changes to the Official Bank Rate by the Bank of England.

Sources: Bloomberg, LexisNexis and Bank of England. Calculations author's own. 
Table 3. Understanding content scores: Financial Times optimistic and pessimistic articles

\begin{tabular}{lll}
\hline \hline & Pessimistic & Optimistic \\
\hline Optimism & 48.01 & 52.01 \\
Date & $29 / 10 / 03$ & $23 / 09 / 02$ \\
\hline Headline & Time to drop bricks and mortar: & House Price Growth Accelerates in \\
& $\begin{array}{l}\text { Diversification and defining returns and } \\
\text { risk are all important }\end{array}$ & September \\
& & \\
\hline
\end{tabular}

Body The mortgage industry has warned borrowers not to put all their money into property, saying they should spread their investments across different assets. Michael Coogan, director-general of the Council of Mortgage Lenders, last month said: "Spreading risk is important, and it is rarely good advice to put all your eggs in one basket."

Mr Coogan, who added that bricks and mortar had "traditionally solid qualities", was speaking as the CML said investors were pouring record sums into buy-to-let loans, in which landlords use rental income to pay mortgage bills.

Banks and building societies lent $£ 7.7 \mathrm{bn}$ for such deals in the first half of 2003, a $40 \%$ year-on-year rise.

The summer lull in the rate of house
price growth is over, according to Rightmove, the online property website.

In its monthly survey of estate agents asking prices, the value of houses rose by $2.3 \%$ in September alone, pushing the increase over the past year up to $22.2 \%$. This was the first rise in the monthly growth rate since April.

The average asking price of property in England and Wales is now more than $£ 150,000$.

Home owners and investors in the buyto-let market may be relieved that rampant housing inflation shows few signs of abating but it will cause concern at the Bank of England.

Mervyn King, the deputy governor, has frequently warned that the big increases over the past few years are "unsustainable" and forecasts that prices will decelerate rapidly from about $20 \%$ annual growth to $3-4 \%$ within two years.

Renewed exuberance in the housing market will reduce the likelihood of an interest rate cut in the near future to boost demand in the economy.

Notes: The above articles were identified as housing market articles published in the Financial Times using LexisNexis's housing market industry tag. The content of the articles was quantified using the content analysis software program Diction. 
Table 4. Details of companies included in housing portfolio

\begin{tabular}{|c|c|c|}
\hline Company & Sector & Years in Sample \\
\hline Ace Liberty \& Stone & REIS & $2007-2012$ \\
\hline All Points North & REIS & 2006-2012 \\
\hline Artisan UK & HGHC & 1998-2012 \\
\hline Barratt Developments & HGHC & 1993-2012 \\
\hline Bellway & HGHC & 1993-2012 \\
\hline Berkeley Group Holdings & HGHC & 1993-2012 \\
\hline Boot Henry & $\mathrm{CM}$ & 1993-2012 \\
\hline Bovis Homes Group & HGHC & $1997-2012$ \\
\hline Caledonian Trust & REIS & 1995-2012 \\
\hline Cardiff Property & REIS & 1993-2012 \\
\hline Conygar Investment Co & REIS & 2003-2012 \\
\hline Daejan & REIS & 1993-2012 \\
\hline Derwint London & REIT & 1993-2011 \\
\hline DTZ Holdings & REIS & 1993-2012 \\
\hline Eatonfield Group & REIS & 2006-2011 \\
\hline Galliford Try & $\mathrm{CM}$ & 1993-2012 \\
\hline Gleeson (MJ) & $\mathrm{CM}$ & 1993-2012 \\
\hline Grainger & REIS & 1993-2012 \\
\hline Hawtin & REIS & 1993-2011 \\
\hline HML Holdings & REIS & 2006-2012 \\
\hline Inland Homes & REIS & 2007-2012 \\
\hline J Smart and Co & $\mathrm{CM}$ & $1993-2012$ \\
\hline LSL Property Services & REIS & 2006-2012 \\
\hline Mar City & REIS & 2005-2012 \\
\hline McKay Securities & REIT & 1993-2012 \\
\hline Mountainview Estates & REIS & $1996-2012$ \\
\hline Northacre & REIS & 1997-2012 \\
\hline O Twelve Estates & REIS & $2006-2012$ \\
\hline Persimmon & HGHC & 1993-2012 \\
\hline Quintain & REIS & $1996-2012$ \\
\hline Redrow & HGHC & 1994-2012 \\
\hline Regent Corp & HGHC & 1993-1994 \\
\hline Renew Holdings & $\mathrm{CM}$ & $1993-2012$ \\
\hline Safeland & REIS & $1993-2012$ \\
\hline Savills & REIS & 1993-2012 \\
\hline St Marks Homes & $\mathrm{CM}$ & 2003-2012 \\
\hline Stewart \& Wight & REIS & 1996-2012 \\
\hline Taylor Wimpey & $\mathrm{HGHC}$ & $1993-2012$ \\
\hline Telford Homes & $\mathrm{HGHC}$ & 2001-2012 \\
\hline Trafalgar New Homes & HGHC & 2006-2012 \\
\hline Wynnstay Properties & REIS & $1995-2012$ \\
\hline
\end{tabular}

Notes: Bloomberg was used to identify companies listed on the London Stock Exchange between 1993 and 2012. Companies were identified from four sectors pertaining to the housing market: Construction and Manufacturing (CM), Household Goods and Home Construction (HGHC), Real Estate Investment Services (REIS) and Real Estate Investment Trusts (REIT). Bloomberg company descriptions were used to ensure that the company's primary activity concerned the UK residential property market. 
Table 5: Newey-West regression results, mean return premium and volume dependent variables, $1,0430 \mathrm{bs}$.

\begin{tabular}{|c|c|c|c|c|c|c|c|c|}
\hline \multirow{2}{*}{ Variable } & \multicolumn{4}{|c|}{ Mean Return Premium } & \multicolumn{4}{|c|}{ Volume } \\
\hline & (1) & (2) & (3) & (4) & (1) & (2) & (3) & (4) \\
\hline \multirow{2}{*}{$\begin{array}{l}F T \\
\text { Optimism }\end{array}$} & $0.165 * * *$ & $0.130 * * *$ & $0.130 * * *$ & $0.103 * *$ & $-0.077 * * *$ & $-0.072 * * *$ & $-0.066^{* *}$ & $-0.037^{*}$ \\
\hline & $(0.057)$ & $(0.049)$ & $(0.049)$ & $(0.045)$ & $(0.024)$ & $(0.024)$ & $(0.024)$ & $(0.022)$ \\
\hline \multirow[t]{2}{*}{ FT Articles } & -0.024 & -0.024 & -0.023 & 0.019 & $0.064 * * *$ & $0.063 * * *$ & $0.063 * * *$ & $0.016^{* *}$ \\
\hline & $(0.022)$ & $(0.020)$ & $(0.020)$ & $(0.019)$ & $(0.009)$ & $(0.009)$ & $(0.009)$ & $(0.008)$ \\
\hline \multicolumn{2}{|l|}{$\begin{array}{l}\text { Volume/ } \\
\text { Return }\end{array}$} & -0.077 & -0.077 & $0.106^{*}$ & & -0.023 & -0.023 & $0.028^{*}$ \\
\hline \multicolumn{2}{|l|}{ Premium } & & & & & & $(0,010)$ & \\
\hline & & & & & & & & \\
\hline \multirow{2}{*}{$\begin{array}{l}\text { FTSE } 100 \\
\text { Return }\end{array}$} & & $0.430 * * *$ & $0.436 * * *$ & $0.429 * * *$ & & -0.008 & -0.006 & -0.020 \\
\hline & & $(0.030)$ & $(0.031)$ & $(0.028)$ & & $(0.015)$ & $(0.014)$ & $(0.013)$ \\
\hline \multirow[t]{2}{*}{ Nationwide } & & & 0.123 & 0.035 & & & $-0.167 * * *$ & -0.066 \\
\hline & & & $(0.100)$ & $(0.095)$ & & & $(0.054)$ & $(0.049)$ \\
\hline \multirow[t]{2}{*}{ OBR } & & & $-1.247 * *$ & $-1.516^{* *}$ & & & $-0.598 * *$ & -0.193 \\
\hline & & & $(0.620)$ & $(0.611)$ & & & $(0.255)$ & $(0.216)$ \\
\hline \multirow[t]{2}{*}{ January } & & & $0.422 * *$ & $0.423 * *$ & & & 0.026 & 0.001 \\
\hline & & & $(0.241)$ & $(0.197)$ & & & $(0.112)$ & $(0.104)$ \\
\hline \multirow[t]{2}{*}{ Crisis } & & & & $-1.597^{* * *}$ & & & & $1.468^{* * *}$ \\
\hline & & & & $(0.278)$ & & & & $(0.067)$ \\
\hline$\overline{\operatorname{Adj~R}^{2}}$ & 0.012 & 0.267 & 0.272 & 0.309 & 0.052 & 0.054 & 0.062 & 0.215 \\
\hline
\end{tabular}

Notes: FT denotes the Financial Times; FTOptimism calculated using Diction. Mean Return and Volume relate to the portfolio of stocks created by author. Nationwide denotes house price changes as announced by the Nationwide Building Society. OBR denotes changes to the Official Bank Rate by the Bank of England. January denotes a January dummy variable. Crisis denotes a dummy variable for all weeks between July 2007 and January 2009 to capture the effects of the financial crisis. 


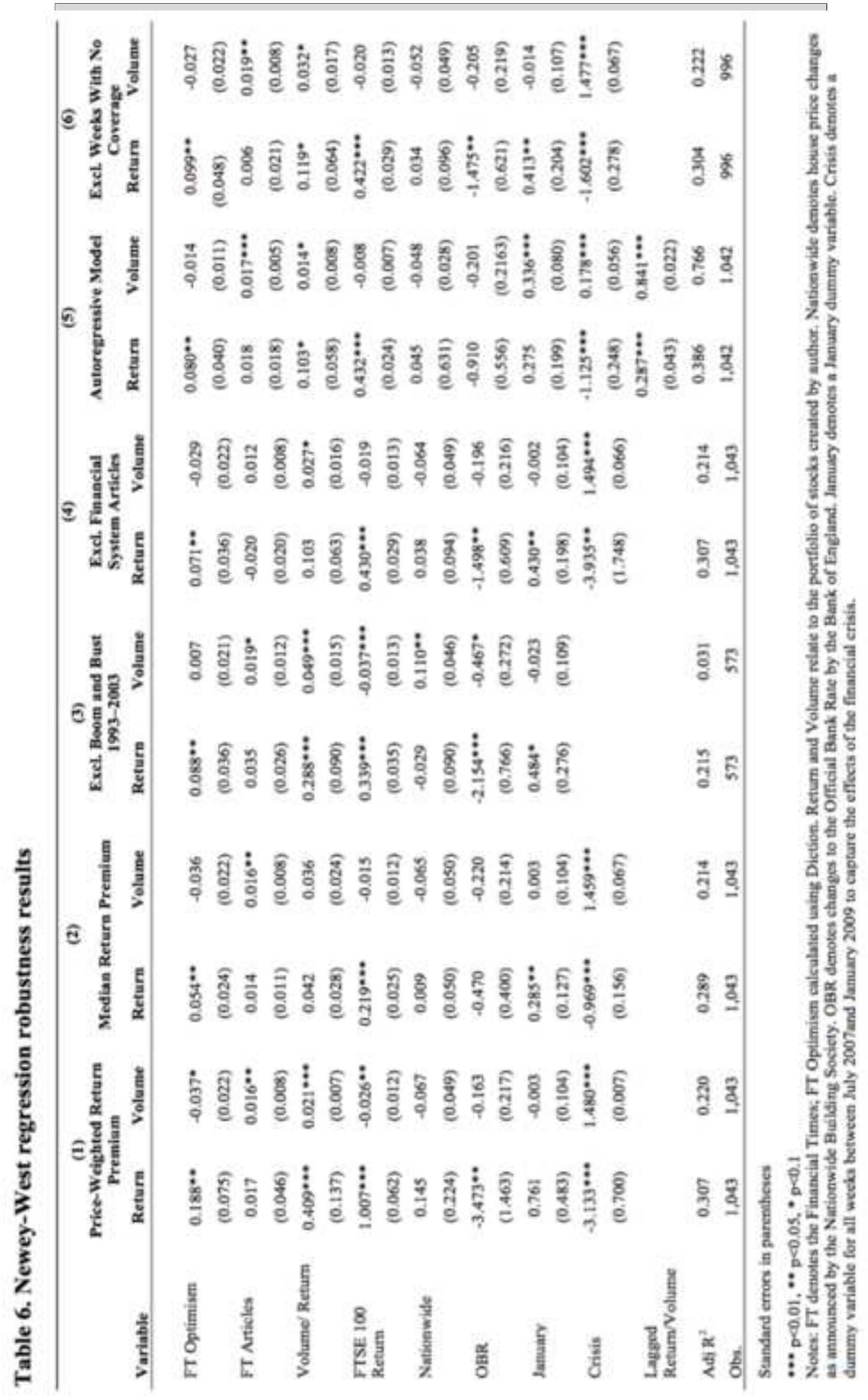


Table 7: Intra-week robustness testing: Newey-West regression results, mean return premium and volume dependent variables.

\begin{tabular}{|c|c|c|c|c|c|c|c|c|}
\hline \multirow{3}{*}{ Variable } & \multicolumn{4}{|c|}{ Using Lagged Media Coverage } & \multicolumn{4}{|c|}{ Excl. Thursday and Friday from Media Coverage } \\
\hline & \multicolumn{2}{|c|}{ Mean Return Premium } & \multicolumn{2}{|c|}{ Volume } & \multicolumn{2}{|c|}{ Mean Return Premium } & \multicolumn{2}{|c|}{ Volume } \\
\hline & (1) & (2) & (3) & (4) & (1) & (2) & (3) & (4) \\
\hline \multirow{2}{*}{$\begin{array}{l}F T \\
\text { Optimism }\end{array}$} & $0.125^{*}$ & $0.070^{*}$ & $-0.074 * * *$ & $-0.066^{* * *}$ & $0.071^{*}$ & $0.061^{*}$ & $-0.069 * * *$ & $-0.062 * * *$ \\
\hline & $(0.075)$ & $(0.042)$ & $(0.024)$ & $(0.024)$ & $(0.038)$ & $(0.033)$ & $(0.020)$ & $(0.020)$ \\
\hline \multirow[t]{2}{*}{ FT Articles } & $-0.055^{* *}$ & $-0.040 * *$ & $0.065 * * *$ & $0.065^{* * *}$ & -0.050 & -0.035 & $0.079 * * *$ & $0.080 * * *$ \\
\hline & $(0.022)$ & $(0.018)$ & $(0.009)$ & $(0.009)$ & $(0.035)$ & $(0.032)$ & $(0.014)$ & $(0.014)$ \\
\hline Volume/ & & -0.067 & & -0.020 & & -0.082 & & -0.026 \\
\hline Premium & & $(0.064)$ & & $(0.020)$ & & $(0.063)$ & & $(0.020)$ \\
\hline \multirow{2}{*}{$\begin{array}{l}\text { FTSE } 100 \\
\text { Return }\end{array}$} & & $0.434 * * *$ & & -0.002 & & $0.437 * * *$ & & -0.004 \\
\hline & & $(0.030)$ & & $(0.015)$ & & $(0.031)$ & & $(0.015)$ \\
\hline \multirow[t]{2}{*}{ Nationwide } & & $0.336^{* *}$ & & $-0.100^{*}$ & & $0.338 * * *$ & & $-0.115^{* *}$ \\
\hline & & $(0.125)$ & & $(0.055)$ & & $(0.128)$ & & $(0.057)$ \\
\hline \multirow[t]{2}{*}{ OBR } & & $-1.388 * *$ & & $-0.493 * *$ & & $-1.356^{* *}$ & & $-0.505 * *$ \\
\hline & & $(0.616)$ & & $(0.218)$ & & $(0.652)$ & & $(0.264)$ \\
\hline \multirow[t]{2}{*}{ January } & & $0.387 *$ & & 0.042 & & $0.418 * *$ & & -0.008 \\
\hline & & $(0.201)$ & & $(0.112)$ & & $(0.200)$ & & $(0.115)$ \\
\hline $\operatorname{Adj~R}^{2}$ & 0.013 & 0.277 & 0.054 & 0.057 & 0.004 & 0.274 & 0.040 & 0.046 \\
\hline
\end{tabular}

Notes: FT denotes the Financial Times; FT Optimism calculated using Diction. Mean Return and Volume relate to the portfolio of stocks created by author. Nationwide denotes house price changes as announced by the Nationwide Building Society. OBR denotes changes to the Official Bank Rate by the Bank of England. January denotes a January dummy variable. 